\title{
Mortality risk factors in lobectomies: Single-institution study
}

Bogdan I. Popovici ${ }^{1}$, Dana Matei ${ }^{2,3, *}$, Anca Daniela Farcas ${ }^{2,4, \dagger}$, Milena Man², Cornelia Popovici ${ }^{4}$, Romeo Chira ${ }^{2,4}$, Cornel lancu ${ }^{2,3}$

${ }^{1}$ Division of Thoracic Surgery, "Leon Daniello" Clinical Hospital of Pneumology Cluj Napoca, Romania

2"Iuliu Hatieganu" University of Medicine and Pharmacy Cluj-Napoca, Romania

3"Prof. O. Fodor" Regional Institute of Gastroenterology and Hepatology, Surgery Department, Cluj-Napoca, Romania

${ }^{4}$ Country Clinical Emergency Hospital Cluj-Napoca, Romania

Abstract

English:

The need to identify the risk factors (RFs) predictive of mortality after pulmonary lobectomy has fuelled several single- or multiinstitution studies, without establishing a prediction model of the generally accepted risk. Each single-institution study offers its own RFs, which corroborated with the RFs published in other multicentric studies may allow a better prediction of postoperative mortality for specific categories of patients. The aim of our study was to identify the 30-day mortality RFs in our lobectomy patients and to compare our results with those published in literature. We therefore analysed the influence of 49 perioperative parameters on postoperative mortality of consecutive lobectomy patients. The 192 lobectomy patients enrolled had malignant $(81.25 \%)$ and infectious conditions (12.5\%) and a $2.6 \%$ mortality rate. The results of our study support the following perioperative RF associated with a high mortality rate: thrombocytosis, chronic obstructive bronchopulmonary disease (COPD), digestive and hepatic comorbidities, neoadjuvant chemotherapy, tuberculosis, the American Society of Anesthesiologists rating and the characteristics of postoperative drainage. In conclusion, these RFs may serve as the factors to consider when calculating the mortality rate after lobectomy, in preoperative selection as well as in instruments for the assessment of postoperative results.

Keywords

\section{Factori de risc asociați cu mortalitatea în lobectomii - studiu unicentric}

Rezumat

\begin{abstract}
Romanian:
Necesitatea identificării factorilor de risc (FR) predictivi ai mortalității postlobectomie a determinat apariția a numeroase studii uni sau multicentrice fără a se putea stabili un model de predicție al riscului general acceptat. Fiecare studiu unicentric susține FR proprii, care asociați cu cei precizați de studile multicentrice ar permite o predicție mai bună a mortalitătii postoperatorii pentru categorii speciale de pacienți. Scopul studiului nostru a fost de a identifica FR pentru mortalitatea la 30 de zile a pacienților cu lobectomie și compararea rezultatelor cu cele din literatura. Au fost analizați 49 parametri perioperatorii și influența asupra mortalității postoperatorii. Cei 192 pacienti înrolați au prezentat patologie malignă (81.25\%) și infectioasă (12.5\%) și au avut o mortalitate postoperatorie de $2.6 \%$. Rezultatele studiului susțin ca FR perioperatori asociați cu o mortalitate crescută au fost trombocitoza, bronhopneumopatia cronica obstructiva, patologia hepato-digestiva, chimioterapia neoadjuvanta, tuberculoza, scor American Society of Anesthesiologists (ASA) crescut și caracteristicile drenajului postoperator. In concluzie, aceștia ar putea constitui factori necesari a fi luați în calculul riscului de mortalitate postlobectomie, în selecția preoperatorie precum și ca instrumente de evaluare a rezultatelor postoperatorii.
\end{abstract}

Cuvinte-cheie

lobectomie $\cdot$ motalitate $\cdot$ evaluarea riscului

${ }^{*}$ Corresponding author: Dana Matei

E-mail: researchdanamatei@gmail.com

${ }^{+}$Authors with equal contribution with first authors. 


\begin{tabular}{|c|c|c|}
\hline \multicolumn{2}{|c|}{ Abbreviations } & \\
\hline ASA & - & \\
\hline COPD & - & $\begin{array}{l}\text { chronic obstructive bronchopulmonary } \\
\text { disease }\end{array}$ \\
\hline FEV1 & - & forced expiratory volumes in $1 \mathrm{~s}$ \\
\hline FEV25-75\% & - & $\begin{array}{l}\text { forced expiratory flow during } 25-75 \% \text { of } \\
\text { expirations }\end{array}$ \\
\hline LLL & - & left lower lobe \\
\hline LUL & - & left upper lobe \\
\hline LVEF\% & - & left ventricle ejection fraction \% \\
\hline ML & - & medium lobe \\
\hline NSCLC & - & non-small-cell lung cancer \\
\hline $\mathrm{P} / \mathrm{Y}$ & - & (cigarette) packs per year \\
\hline $\mathrm{PaO}_{2}$ & - & partial pressure of oxygen in arterial blood \\
\hline $\mathrm{PaCO}_{2}$ & - & $\begin{array}{l}\text { partial pressure of carbon dioxide in arterial } \\
\text { blood }\end{array}$ \\
\hline PAPs & - & pulmonary artery pressures \\
\hline ppoFEV1 & - & $\begin{array}{l}\text { predicted postoperative forced expiratory } \\
\text { volumes in } 1 \mathrm{~s}\end{array}$ \\
\hline RF & - & risk factors \\
\hline RLL & - & right lower lobe \\
\hline RUL & - & right upper lobe \\
\hline $\mathrm{SaO}_{2}$ & - & Oxygen saturation (arterial blood) \\
\hline TB & - & tuberculosis \\
\hline TLC\% & - & total lung capacity\% \\
\hline
\end{tabular}

\section{Introduction}

Radical pulmonary resections are the most efficient option for the therapy of pulmonary cancer (1-3) and of other benign pulmonary conditions. Of all radical pulmonary resections, lobectomy is the most frequently used. Usually, this intervention has severe cardiac and respiratory consequences and it is performed on frail patients with several functional impairments and comorbidities (1). During the past four decades, several studies on the characteristics of patients at high mortality risk after pulmonary resection have been performed (4-7).

These studies are "single-institution studies", of limited size, and present the characteristics of the local patients and institution, making the results difficult to extrapolate to other institutions (2).

Since these studies define sets of risk factors (RFs) specific to the group being analysed, they cannot be compared with the results of other institutions in order to assess the performance of the surgical act $(8,9)$. Including single-institution studies in large national or multinational databases may prove useful in creating a standard to which each institution may compare its surgical performance (6). This standard, despite its high statistical value, may not accurately reflect the experience of just a single institution (4). It follows that the best practice would be to perform studies assessing the local activity of each centre alongside including these data in large multiinstitutional databases.

This study is based on the assumption that the mortality RFs of pulmonary lobectomies, identified through multiinstitutional studies $(1,5,6)$, may be insufficient in correctly assessing mortality in our clinic. Specific factors, correlated with the particularities of the patients and of the institution, may be present. A risk prediction model, also including these factors, may be more useful in the accurate assessment of the surgical risk. The aim of this study was to assess the mortality predictive factors in consecutive patients having undergone lobectomy. In case of finding specific RFs, these factors may prove useful in improving the postoperative mortality prediction and in assessing the quality of the surgical act, both medically and legally.

\section{Material and method}

We enrolled in this study all consecutive patients having undergone lobectomy, especially for pulmonary cancer as well as for benign conditions. The surgical interventions were performed by the same anaesthesia/surgical team using a single protocol in a regional thoracic centre between 2008 and 2014.

Following parameters were recorded: demographic data, preoperative functional status, comorbidities and particularities of each condition. We recorded in the database the neoplastic stages using the TNM 7 classification (7). Other parameters included the duration of surgery and the particularities of postoperative drainage, among others, amounting to 49 perioperative variables. The only postoperative variable recorded was the 30-day mortality rate, meant to determine which of the previous parameters may become mortality RFs after lobectomy. All patients signed an informed consent. The study was approved by the Ethics Committee of "Iuliu Hațieganu" University of Medicine and Pharmacy no 29/05.05.2018.

The statistical analysis was performed using the IMB SPSS Statistics 2.0 software.

We analysed over 49 pre- and intraoperative variables, 37 categorical and 12 continuous, in order to identify some possible correlations with postoperative mortality. The categorical variables were compared using the Chi-square teste $\left(\chi^{2}\right)$ or Fisher test when necessary. For the continuous variables we identified the normally or abnormally distributed variables, expressed them as means or medians and tested them using the Student's $t$ and Mann-Whitney tests. 
Using the univariate analysis, we identified which of the mentioned preoperative factors influenced postoperative mortality with statistical significance $(p<0.05)$.

The variables identified were introduced in multivariate analysis in order to determine which may qualify as independent predictive factors.

\section{Results}

We enrolled 264 patients with major pulmonary resections, after excluding 34 because of incomplete medical data. Of these, 192 patients required lobectomy $(72.7 \%)$, 20 bilobectomy $(7.5 \%)$ and 52 pneumonectomy (19.7\%). The mean age of patients was $57.4 \pm 11.1$ years (17-79 years); the majority were male $(72.4 \%)$ and smokers of more than 20 packs of cigarettes per year (81.3\%). The surgical indication was established for malignant $(81.25 \%$ cases - of which $4.2 \%$ carcinoids), infectious [ $12.5 \%$ cases - of which $6.8 \%$ tuberculosis (TB)] and benign conditions $(6.25 \%$ - including rare conditions). Two patients (1.04\%) had TB in addition to their malignancy, and $8.5 \%$ of pulmonary tumours were either infected or associated with non-tuberculous infections.

The 30-day postoperative mortality rate for lobectomy was $2.6 \%$, for bilobectomy was $5 \%$ and for pneumonectomy was $5.9 \%$. The patients' functional characteristics and laboratory results are displayed in Table 1.

The patients who expired were all male and had lower TLC, $\mathrm{SaO}_{2}, \mathrm{PaO}_{2}, \mathrm{PaCO}_{2}$ values, compared with those who survived, but the difference did not reach statistical significance. In addition, the former more often had leucocytosis, anaemia or thrombocytosis, but only the latter was statistically significant. Patients who died had a higher frequency of comorbidities apart from neuropsychiatric, osteoarticular, skin and metabolic conditions, diabetes mellitus and kidney failure (Table 2). Despite the higher incidence of cardiovascular, respiratory, urogenital and hepato-digestive diseases, only the latter and chronic obstructive disease (COPD) reached statistical significance. Furthermore, neoadjuvant chemotherapy was performed more frequently (with statistical significance) in patients who did not survive. The pathology data of patients with lobectomy are displayed in Table 3, which show a higher frequency of infections, especially TB, in patients who died $(p<0.05)$. Table 4 shows that these patients more frequently had an indication for emergency lobectomy, American Society of Anesthesiologists (ASA) classes III and IV and right-side lobectomy. The mean duration of surgery was $3.19 \pm 1.02 \mathrm{~h}$, without significant difference between the two groups of patients. The postoperative pleural drainage (detailed in Table 5) was more abundant in the first and second day after the surgery of patients who died. We considered as normal drainage the discharge of serosanguinous or citrine fluid, but not the postoperative haemorrhagic discharge, which we classified separately. The patients who did not survive had a larger quantity of drainage fluid, with a $650 \mathrm{~mL}$ cut-off for Day 1 (Se $60 \%$ and Sp $81.82 \%$ ) and $550 \mathrm{~mL}$ for Day 2 (Se $40 \%$ and Sp $96.26 \%$ ).

Table 1. Functional and laboratory characteristics of patients

\begin{tabular}{|c|c|c|c|c|}
\hline \multirow[t]{2}{*}{ Analysed factor } & \multirow{2}{*}{$\begin{array}{l}\text { All: } 192 \\
\text { No. }(\%)\end{array}$} & \multicolumn{2}{|c|}{ Postoperative death } & \multirow[t]{2}{*}{$p$} \\
\hline & & No 187 (97.4\%) & Yes $5(2.6 \%)$ & \\
\hline Age (years) & $57.48 \pm 11.11$ & $57.35 \pm 10.99$ & $62.40 \pm 15.58$ & 0.317 \\
\hline Male sex & $139(72.4 \%)$ & $134(71.7 \%)$ & $5(100 \%)$ & 0.325 \\
\hline Smoking [ $>20$ packs per year $(P / Y)]$ & $156(81.3 \%)$ & $152(81.3 \%)$ & $4(80.0 \%)$ & 1.000 \\
\hline Total lung capacity\% (TLC\%) & $77.73 \pm 14.12$ & $84.42 \pm 14.85$ & $77.55 \pm 14.10$ & 0.284 \\
\hline FEV1\% & $84.34 \pm 16.68$ & $80.04 \pm 15.26$ & $84.45 \pm 16.75$ & 0.561 \\
\hline FEV25-75\% & $74.43 \pm 28.45$ & $60.20 \pm 29.22$ & $74.82 \pm 28.41$ & 0.258 \\
\hline Oxygen saturation (arterial blood) $\left(\mathrm{SaO}_{2}\right)$ & $95.55 \pm 2.89$ & $96.64 \pm 1.13$ & $95.52 \pm 2.92$ & 0.393 \\
\hline Partial pressure of oxygen in arterial blood $\left(\mathrm{PaO}_{2}\right)$ & $81.35 \pm 17.93$ & $84.40 \pm 8.40$ & $81.27 \pm 18.12$ & 0.701 \\
\hline Partial pressure of carbon dioxide in arterial blood $\left(\mathrm{PaCO}_{2}\right)$ & $39.04 \pm 5.22$ & $40.52 \pm 2.60$ & $39.00 \pm 5.27$ & 0.522 \\
\hline $\mathrm{pH}$ & $7.38 \pm 0.05$ & $7.37 \pm 0.03$ & $7.38 \pm 0.05$ & 0.581 \\
\hline Pulmonary artery pressures (PAPs) & $28.74 \pm 6.12$ & $32.40 \pm 2.51$ & $28.65 \pm 6.16$ & 0.176 \\
\hline Left ventricle ejection fraction\% (LVEF\%) & $55.09 \pm 5.67$ & $54.60 \pm 4.45$ & $55.10 \pm 5.71$ & 0.846 \\
\hline Leucocytosis & $77(40.1 \%)$ & $73(39.0 \%)$ & $4(80.0 \%)$ & 0.159 \\
\hline Anaemia & $103(53.6 \%)$ & $99(52.9 \%)$ & $4(80.0 \%)$ & 0.375 \\
\hline Thrombocytosis & $20(10.4 \%)$ & $17(9.1 \%)$ & $3(60.0 \%)$ & 0.009 \\
\hline Inflammatory markers & $117(60.9 \%)$ & $114(61.0 \%)$ & $3(60.0 \%)$ & 1.000 \\
\hline
\end{tabular}

$P$ value was considered significant if $p<0.05$ 
Table 2. Comorbidities of lobectomy patients

\begin{tabular}{|c|c|c|c|c|}
\hline \multirow[t]{2}{*}{ Analysed factor } & \multirow{2}{*}{$\begin{array}{l}\text { All: } 192 \\
\text { No. (\%) }\end{array}$} & \multicolumn{2}{|c|}{ Postoperative death } & \multirow[t]{2}{*}{$p$} \\
\hline & & No $187(97.4 \%)$ & Yes $5(2.6 \%)$ & \\
\hline Cardiovascular conditions & $98(51.0 \%)$ & $95(50.8 \%)$ & $3(60.0 \%)$ & 1.000 \\
\hline Diastolic dysfunction & $46(24.0 \%)$ & $44(23.5 \%)$ & $2(40.0 \%)$ & 0.595 \\
\hline Respiratory disease & $79(41.1 \%)$ & $75(40.1 \%)$ & $4(80.0 \%)$ & 0.161 \\
\hline COPD & $65(33.9 \%)$ & $61(32.6 \%)$ & $4(80.0 \%)$ & 0.046 \\
\hline Neuro-psychiatric conditions & $16(8.3 \%)$ & $16(8.6 \%)$ & $0(0.0 \%)$ & 1.000 \\
\hline Metabolic diseases & $41(21.4 \%)$ & $41(21.9 \%)$ & $0(0.0 \%)$ & 0.586 \\
\hline Diabetes mellitus & $15(7.8 \%)$ & $15(8.0 \%)$ & $0(0.0 \%)$ & 1.000 \\
\hline Urogenital conditions & $14(7.3 \%)$ & $13(7.0 \%)$ & $1(20 \%)$ & 0.318 \\
\hline Kidney failure & $9(4.7 \%)$ & $9(4.8 \%)$ & $0(0.0 \%)$ & 1.000 \\
\hline Digestive conditions & $36(18.8 \%)$ & $33(17.6 \%)$ & $3(60.0 \%)$ & 0.046 \\
\hline Osteoarticular conditions & $15(7.8 \%)$ & $15(8.0 \%)$ & $0(0.0 \%)$ & 1.000 \\
\hline Skin diseases & $6(3.1 \%)$ & $6(3.2 \%)$ & $0(0.0 \%)$ & 1.000 \\
\hline Associated cancers & $19(9.9 \%)$ & $18(9.6 \%)$ & $1(20.0 \%)$ & 0.410 \\
\hline Number of comorbidities & $1.81 \pm 1.717$ & $1.80 \pm 1.723$ & $2.40 \pm 1.517$ & 0.440 \\
\hline Neoadjuvant chemotherapy & $55(28.6 \%)$ & $51(27.3 \%)$ & $4(80 \%)$ & 0.024 \\
\hline Preoperative radiotherapy & $5(2.6 \%)$ & $5(2.7 \%)$ & $0(0.0 \%)$ & 1.000 \\
\hline
\end{tabular}

$P$ value was considered significant if $p<0.05$

Table 3. Pathological characteristics of patients having undergone lobectomy

\begin{tabular}{|c|c|c|c|c|c|}
\hline \multirow[t]{2}{*}{ Analysed factor } & & \multirow{2}{*}{$\begin{array}{l}\text { All: } 192 \\
\text { No. (\%) }\end{array}$} & \multicolumn{2}{|c|}{ Postoperative death } & \multirow[t]{2}{*}{$p$} \\
\hline & & & No $187(97.4 \%)$ & Yes $5(2.6 \%)$ & \\
\hline \multirow[t]{3}{*}{ Associated infections } & Nonspecific & $40(20.8 \%)$ & $39(20.9 \%)$ & $1(20.0 \%)$ & 0.001 \\
\hline & TB & $13(6.8 \%)$ & $11(5.9 \%)$ & $2(40.0 \%)$ & \\
\hline & No infection & $139(72.4 \%)$ & $137(73.3 \%)$ & $2(40 \%)$ & \\
\hline \multirow[t]{2}{*}{ TB } & Without TB & $179(93.2 \%)$ & $176(94.1 \%)$ & $3(60 \%)$ & 0.036 \\
\hline & With TB & $13(6.8 \%)$ & $11(5.9 \%)$ & $2(40.0 \%)$ & \\
\hline \multirow[t]{10}{*}{ Pathological diagnosis } & Abscess & $10(5.2 \%)$ & $10(5.3 \%)$ & $0(0.0 \%)$ & 0.155 \\
\hline & Benign & $3(1.6 \%)$ & $3(1.6 \%)$ & $0(0.0 \%)$ & \\
\hline & Bronchiectasis & $3(1.6 \%)$ & $3(1.6 \%)$ & $0(0.0 \%)$ & \\
\hline & Adenocarcinoma & $68(35.4 \%)$ & $65(34.8 \%)$ & $3(60.0 \%)$ & \\
\hline & Carcinoma & $43(22.4 \%)$ & $43(23.0 \%)$ & $0(0.0 \%)$ & \\
\hline & Other NSCLC & $27(14.1 \%)$ & $27(14.4 \%)$ & $0(0.0 \%)$ & \\
\hline & Sarcoma & $9(4.7 \%)$ & $9(4.8 \%)$ & $0(0.0 \%)$ & \\
\hline & Carcinoid & $8(4.2 \%)$ & $8(4.7 \%)$ & $0(0.0 \%)$ & \\
\hline & TB & $11(4.2 \%)$ & $9(4.8 \%$ & $2(18.8 \%)$ & \\
\hline & Other rare findings & $9(4.7 \%)$ & $9(4.8 \%)$ & $0(0.0 \%)$ & \\
\hline Malignant conditions & & $157(81.8 \%)$ & $154(82.4 \%)$ & $3(60 \%)$ & 0.225 \\
\hline Benign conditions & & $35(18.2 \%)$ & $33(17.6 \%)$ & $2(40.0 \%)$ & 0.225 \\
\hline \multirow[t]{7}{*}{ TNM 7 stages } & $\mathrm{IA}$ & $11(5.7 \%)$ & $9(4.8 \%)$ & $2(40.0 \%)$ & 0.054 \\
\hline & IB & $31(16.1 \%)$ & $31(16.6 \%)$ & $0(0.0 \%)$ & \\
\hline & $\| \mathrm{A}$ & $36(18.8 \%)$ & $36(19.3 \%)$ & $0(0.0 \%)$ & \\
\hline & IIB & $35(18.2 \%)$ & 34 (18.2\%) & $1(20.0 \%)$ & \\
\hline & IIIA & $26(13.5 \%)$ & $26(13.9 \%)$ & $0(0.0 \%)$ & \\
\hline & IIIB & 7 (3.6\%) & 7 (3.7\%) & $0(0.0 \%)$ & \\
\hline & IV & $4(2.1 \%)$ & $4(2.1 \%)$ & $0(0.0 \%)$ & \\
\hline
\end{tabular}

$P$ value was considered significant if $p<0.05$ 
It follows that $950 \mathrm{~mL}$ of pleural fluid drained during the first 2 days correlates with a higher mortality risk, at $60 \%$ Se and $81.82 \% \mathrm{Sp}$. The mortality rate was significantly higher in case of haemorrhagic drainage exceeding $1,500 \mathrm{~mL}$ in the first $48 \mathrm{~h}$. The multivariate analysis showed that none of the analysed RFs, namely preoperative thrombocytosis, COPD or hepato-digestive conditions, neoadjuvant chemotherapy, associated TB, >550 mL drained fluid on the second day and postoperative haemorrhage exceeding $1,500 \mathrm{~mL}$ in the first $48 \mathrm{~h}$, had a predictive ability for postoperative mortality (Table 6). It is noteworthy that, despite not reaching statistical significance, TB and thrombocytosis

Table 4. Characteristics of the anaesthesia and surgery

\begin{tabular}{|c|c|c|c|c|c|}
\hline \multicolumn{2}{|c|}{ Analysed factor } & \multirow{2}{*}{$\begin{array}{l}\text { All: } 192 \\
\text { No. }(\%)\end{array}$} & \multicolumn{2}{|c|}{ Postoperative death } & \multirow[t]{2}{*}{$p$} \\
\hline & & & No $187(97.4 \%)$ & Yes $5(2.6 \%)$ & \\
\hline Previous thoracotomy & & $7(3.6 \%)$ & $7(3.7 \%)$ & $0(0.0 \%)$ & 1.000 \\
\hline Emergency lobectomy & & $6(3.1 \%)$ & $5(2.7 \%)$ & $1(20 \%)$ & 0.148 \\
\hline \multirow[t]{4}{*}{ ASA } & I & $8(4.2 \%)$ & $8(4.3 \%)$ & $0(0.0 \%)$ & $<0.001$ \\
\hline & II & $79(41.1 \%)$ & $78(41.7 \%)$ & $1(20.0 \%)$ & \\
\hline & III & $104(54.2 \%)$ & $101(54.0 \%)$ & $3(60.0 \%)$ & \\
\hline & IV & $1(0.5 \%)$ & $0(0.0 \%)$ & $1(20.0 \%)$ & \\
\hline \multirow[t]{5}{*}{ Lobectomy } & Right upper lobe (RUL) & $49(25.5 \%)$ & $47(25.1 \%)$ & $2(40.0 \%)$ & 0.188 \\
\hline & Medium lobe (ML) & $12(6.3 \%)$ & $12(6.4 \%)$ & $0(0.0 \%)$ & \\
\hline & Right lower lobe (RLL) & $44(22.9 \%)$ & $41(21.9 \%)$ & $3(60.0 \%)$ & \\
\hline & Left upper lobe (LUL) & $47(24.5 \%)$ & $47(25.1 \%)$ & $0(0.0 \%)$ & \\
\hline & Left lower lobe (LLL) & $40(20.8 \%)$ & $40(21.4 \%)$ & $0(0.0 \%)$ & \\
\hline Duration of intervention & & $3.19 \pm 1.02$ & $3.20 \pm 1.03$ & $3.02 \pm 1.04$ & 0.704 \\
\hline
\end{tabular}

$P$ value was considered significant if $p<0.05$

Table 5. Characteristics of postoperative pleural drainage in the study group

\begin{tabular}{|c|c|c|c|c|}
\hline \multirow[t]{2}{*}{ Analysed factor } & \multirow{2}{*}{$\begin{array}{l}\text { All: } 192 \\
\text { No. }(\%)\end{array}$} & \multicolumn{2}{|c|}{ Postoperative death } & \multirow[t]{2}{*}{$p$} \\
\hline & & No $187(97.4 \%)$ & Yes $5(2.6 \%)$ & \\
\hline Drainage Day 1 (mL) & $497.92 \pm 226.91$ & $492.51 \pm 221.00$ & $700 \pm 367.42$ & 0.043 \\
\hline Drainage Day $1>650$ mL (cut-off) & $37(19.3 \%)$ & $34(18.2 \%)$ & $3(60.0 \%)$ & 0.050 \\
\hline Drainage Day $2(\mathrm{~mL})$ & $273.70 \pm 139.70$ & $268.72 \pm 128.67$ & $460.00 \pm 343.51$ & 0.002 \\
\hline Drainage Day $2>550$ mL (cut-off) & $9(4.7 \%)$ & $7(3.7 \%)$ & $2(40 \%)$ & 0.007 \\
\hline Drainage Day $1+$ Day $2>950 \mathrm{~mL}$ (cut-off) & $37(19.3 \%)$ & $34(18.2 \%)$ & $3(60.0 \%)$ & 0.050 \\
\hline Haemorrhage Day $1>1,000 \mathrm{~mL}$ & $12(6.3 \%)$ & $11(5.9 \%)$ & $1(20.0 \%)$ & 0.278 \\
\hline Haemorrhage Day $1+$ Day $2>1,500 \mathrm{~mL}$ & $13(6.8 \%)$ & $11(5.9 \%)$ & $2(40.0 \%)$ & 0.038 \\
\hline
\end{tabular}

$P$ value was considered significant if $p<0.05$

Table 6. The impact of RFs on mortality in lobectomies as found in multivariate analysis

\begin{tabular}{|c|c|c|c|c|}
\hline \multirow{2}{*}{ Variable/RF } & \multirow{2}{*}{$\operatorname{Exp}(B)$} & \multirow{2}{*}{ Sig. } & \multicolumn{2}{|c|}{$95 \% \mathrm{Cl}$ for $\operatorname{Exp}(\mathrm{B})$} \\
\hline & & & Lower & Upper \\
\hline Thrombocytosis & 7.41 & 0.142 & 0.51 & 107.77 \\
\hline COPD & 2.45 & 0.543 & 0.14 & 44.16 \\
\hline Digestive conditions & 4.89 & 0.2566 & 0.32 & 75.69 \\
\hline Neoadjuvant chemotherapy & 2.03 & 0.615 & 0.13 & 31.69 \\
\hline TB & 11.39 & 0.098 & 0.64 & 203.35 \\
\hline Drainage Day $2>550 \mathrm{~mL}$ & 2.63 & 0.580 & 0.15 & 221.42 \\
\hline Haemorrhage $>1,500 \mathrm{~mL}$ & 5.84 & 0.314 & 0.15 & 221.42 \\
\hline
\end{tabular}

$P$ value was considered significant if $p<0.05$ 
were correlated with an increase in mortality risk of 11.39and 7.41-folds, respectively.

\section{Discussion}

Two hundred and ninety-four patients who consecutively underwent lobectomy or radical pneumectomy were evaluated. Conditions associated with high mortality rate in our study were: thrombocytosis, COPD, digestive and hepatic comorbidities, neoadjuvant chemotherapy, TB, high ASA score and the characteristics of postoperative drainage.

Several studies, either single- or multi-institutional, have analysed several RFs in the search of those capable to predict the 30-day mortality. Despite the fact, that there is no accepted model for the prediction of mortality after lobectomy (10), the studies have identified several mortality RFs that deserve consideration. For instance, Brunelli and colab (5), while analysing the data of the European Society of Thoracic Surgeons Data Base, including around 48,000 anatomic resections of which 36,376 lobectomies, found the following parameters to predict mortality independently: male sex, age, predicted postoperative forced expiratory volumes in $1 \mathrm{~s}$ (ppoFEV1), coronary ischaemic disease, cerebrovascular disease, body mass index and thoracotomy. In an American study, performed by the Society of Thoracic Surgeons (1), the analysis of over 27,000 resections yielded a series de new predictive factors, completing the European model for the prediction of mortality risk: steroids, peripheral vascular disease, renal dysfunction, the Zubrod score, the ASA rating, induction therapy, tumour stage and extension of resection, re-interventions and the thoracotomy approach. The study performed on the national French database Epithor (6), including over 18,000 resections, has identified the following mortality RFs: age, sex, the ASA score, performance status, forced expiratory volume, body mass index, the side and type of lung resection, the need for extended resection, stage and number of comorbidities per patient. Another study (8) performed on around 3,000 lobectomies found other independent RFs: hypoalbuminaemia, "do not resuscitate" status, transfusions of more than four blood units, age, disseminated cancer, impaired sensorium, prothrombin time, type of operation and dyspnoea, while the study performed by Jean et al. (10) mentions dyspnoea at rest, dyspnoea on exertion and dysnatraemia.

It follows that the aforementioned literature does not offer the basis for a generally applicable prediction model for 30-day mortality after lobectomy $(9,11)$ which makes the analysis of each local group essential in finding risk models specific to each institution.
In these circumstances, our study analysed 49 presumed perioperative RFs for 30-day mortality, on a group of 192 consecutive patients having undergone lobectomy; we identified a series of clinical, biological, pathological and surgical/anaesthetic characteristics found more frequently in patients who did not survive than in those who did.

In our study, the 30-day mortality rate in lobectomy patients was $2.6 \%$, similar to that previously published. All deceased patients were male, since the male sex is a RF confirmed by other studies $(1,5,6)$. In addition, we found several other RFs found more frequently in deceased patients, with differences sometimes reaching statistical significance: thrombocytosis, COPD, hepatic or digestive conditions, induction chemotherapy, ASA classes III and IV and the presence of suppurations, especially TB.

Thrombocytosis (a platelet count above $40 \times 10^{4} / \mathrm{mL}$ ) was defined as a RF for increased morbidity and mortality in oncological surgery for colorectal (12), gynaecological (in association with leucocytosis) (13) and pulmonary cancers (14). Kim et al. (14) found that preoperative thrombocytosis increases the mortality 2.47-fold in non-small-cell lung cancer (NSCLC) patients. In our study, thrombocytosis was more frequent than in Kim et al.'s study (10.4 vs $7.5 \%$ ) and correlated with a 7.41-fold higher mortality risk in patients with varied pulmonary conditions. A possible explanation of the differences in study results may reside in our large number of cases associating nonspecific or TB infection to the neoplasia. Furthermore, our group also included patients in whom the surgical indication was prompted by the infectious condition. To our knowledge, none of the above-mentioned studies found infections as a 30-day mortality risk and yet, the high incidence of infections (specific and nonspecific) we found in patients who did not survive warns that they should be considered an individual RF for a certain category of patients. In addition, in our study, pulmonary TB increased the mortality risk 11.39-fold but did not validate as an independent RF due to the lack of statistical significance. COPD (GOLD $1-3)$, frequent in patients undergoing surgery, is also an independent RF for death in these patients (1, 15-17). In our study, despite its significantly higher prevalence in patients who died, the multivariate analysis did not confirm it as an independent mortality RF.

Digestive conditions, especially toxic liver disease, further weaken these patients by altering the albumin levels and coagulation tests, increasing the risk of death 4.89-fold, but without having an independent predictive value.

The published data are consistent in stating neoadjuvant chemotherapy as having a severe impact on morbidity and mortality after lung resections, leading to a $2.4 \%$ mortality rate (18-21), confirmed by our study.

A high incidence of ASA classes III and IV in deceased patients confirms the data in literature but a higher mortality rate in 
patients with right-side lobectomies, as found in our study, has not been previously mentioned. Further studies focused on this issue may provide pathophysiological explanations for this finding, as well as therapeutic implications in order to decrease mortality.

In our study, of the postoperative parameters, we chose only pleural drainage, considering it as a direct consequence of the surgical act (22). Drainage of serous/citrine pleural fluid was the desired postoperative outcome, since the process allows its early removal with all the subsequent advantages (early mobilization, decreased infectious risk, increased compliance to respiratory physiotherapy) (23). In our clinic, the drainage after lobectomy involves two drains which are removed when the fluid becomes serous/ citrine and falls below $200-300 \mathrm{~mL}$. The analysis of our data found that volumes of at least $650 \mathrm{~mL}$ on the first day and $550 \mathrm{~mL}$ on the second day may identify patients at higher mortality risk. These volumes may be caused by inflammatory conditions in the lung or pleura, difficult or late postoperative haemostasis or difficult expansion of the remaining parenchyma. In addition, some factors such as hypoalbuminaemia or haemodynamic imbalances may lead to prolonged drainage and higher mortality. Furthermore, haemorrhagic drainage, exceeding $1,500 \mathrm{~mL}$ in the first $48 \mathrm{~h}$, was also associated with higher mortality. This association, despite good intraoperative haemostasis, may suggest general (hepatopathies, vascular conditions, etc.) or local factors (pleural adhesions, pleural and pulmonary suppurations, TB, lung diseases which make the expansion of the remaining parenchyma difficult). In our experience, the cases in whom haemodynamic stabilization was obtained by specific intensive care procedures and who did not develop large intrapleural clots did not require further interventions for haemostasis.

Despite the differences found between patients who died and those who survived, the multivariate analysis did not yield any independent 30 -day mortality predictors, probably due to the low number of deaths.

One explanation of this fact may reside in certain limitations of our study: (a) the relatively short interval of analysis - the 90-day mortality analysis may provide further information; (b) the size of our study group as well as the low number of deaths; (c) the selection of variables, based on the analysis of medical records (for instance, the lack of important parameters such as diffusion lung capacity for carbon monoxide (DLCO), ppoFEV1, albumin levels, etc.); (d) the use of thoracotomy alone, known to be a mortality predictor $(1,5,10)$, rather than the minimally invasive approach preferable to thoracotomy (24-26), which may all distort the results.

Despite these limitations, the results of our study may serve as the foundation for a basic model for the prediction of postoperative risk specific to the study group or to other similar groups, to be improved by further studies in the field.

\section{Conclusion}

When multicentric studies do not provide a generally applicable predictive model for 30-day mortality after lobectomy, our single-institution study suggests that factors such as thrombocytosis, COPD, liver and digestive conditions, induction chemotherapy, the ASA rating, associated suppurations - especially TB, the volume and characteristics of pleural drainage may constitute the necessary factors to be considered in calculating the mortality rate after lobectomy, in preoperative selection as well as in assessing the postoperative results.

\section{Ethics approval and consent to participate}

The study was approved by the Ethics Committee of "Iuliu Hațieganu" University of Medicine and Pharmacy no 29/05.05.2018.

\section{Conflicts of interest}

The authors declare that they have no conflicts of interest.

\section{References}

1. Fernandez FG, Kosinski AS, Burfeind W, Park B, DeCamp MM, Seder $C$, et al. The society of thoracic surgeons lung cancer resection risk model: Higher quality data and superior outcomes. The Annals of Thoracic Surgery. 2016;102(2): 370-377.

2. Bernard A, Ferrand L, Hagry O, Benoit L, Cheynel N, Favre JP. Identification of prognostic factors determining risk groups for lung resection. The Annals of Thoracic Surgery. 2000;70(4): 1161-1167.

3. Ferguson MK, Reeder LB, Mick R. Optimizing selection of patients for major lung resection. The Journal of Thoracic and Cardiovascular Surgery. 1995;109(2): 275-283.

4. Kamel MK, Lee B, Harrison S, Port JL, Pua B, Altorki NK, et al. Do the surgical results in the National Lung Screening Trial reflect modern thoracic surgical practice? The Journal of Thoracic and Cardiovascular Surgery. 2019;157(5): 2038. e1-2046.e1.

5. Brunelli A, Salati M, Rocco G, Varela G, Van Raemdonck D, Decaluwe $\mathrm{H}$, et al. European risk models for morbidity (EuroLung1) and mortality (EuroLung2) to predict outcome following anatomic 
lung resections: An analysis from the European Society of Thoracic Surgeons database. European Journal of Cardio-Thoracic Surgery. 2016;51(3): ezw319.

6. Bernard A, Rivera C, Pages PB, Falcoz PE, Vicaut E, Dahan M. Risk model of in-hospital mortality after pulmonary resection for cancer: A national database of the French Society of Thoracic and Cardiovascular Surgery (Epithor). The Journal of Thoracic and Cardiovascular Surgery. 2011;141(2): 449-458.

7. Mirsadraee S, Oswal D, Alizadeh Y, Caulo A, van Beek E Jr. The 7th lung cancer TNM classification and staging system: Review of the changes and implications. World Journal of Radiology. 2012 Apr 28;4(4): 128-134.

8. Harpole DH, DeCamp MM, Daley J, Hur K, Oprian CA, Henderson WG, et al. Prognostic models of thirty-day mortality and morbidity after major pulmonary resection. The Journal of Thoracic and Cardiovascular Surgery. 1999;117(5): 969-979.

9. Postmus PE, Kerr KM, Oudkerk M, Senan S, Waller DA Vansteenkiste $\mathrm{J}$ et al. Early and locally advanced non-small-cell lung cancer (NSCLC): ESMO Clinical Practice Guidelines for diagnosis, treatment and follow-up. Available from: https:// academic.oup.com/annonc/article-abstract/28/suppl_4/ iv1/3958156.

10. Jean RA, DeLuzio MR, Kraev Al, Wang G, Boffa DJ, Detterbeck FC, et al. Analyzing risk factors for morbidity and mortality after lung resection for lung cancer using the NSQIP database. Journal of the American College of Surgeons. 2016;222(6): 992.e1-1000.e1.

11. Salati M, Brunelli A. Risk stratification in lung resection. Current Surgery Reports. 2016;4(11): 37.

12. Mohamud M, Osborne L, Jones HG, Ahmed A, Beynon J, Harris DA, et al. Thrombocytosis as a marker for postoperative complications in colorectal surgery. Gastroenterology Research and Practice. 2018;2018: 1-5.

13. Andersen CL, Eskelund CW, Siersma VD, Felding P, Lind B, Palmblad $\mathrm{J}$, et al. Is thrombocytosis a valid indicator of advanced stage and high mortality of gynecological cancer? Gynecologic Oncology. 2015;139(2): 312-318.

14. Kim M, Chang $\mathrm{H}$, Yang $\mathrm{H}$, Kim YJ, Lee C-T, Lee J-H, et al. Preoperative thrombocytosis is a significant unfavorable prognostic factor for patients with resectable non-small cell lung cancer. World Journal of Surgical Oncology. 2014; 12(1): 37.

15. Gupta H, Ramanan B, Gupta PK, Fang X, Polich A, Modrykamien $A$, et al. Impact of COPD on postoperative outcomes. Chest. 2013;143(6): 1599-1606.
16. Saji $H$, Miyazawa $T$, Sakai $H$, Kimura $Y$, Tsuda $M$, Wakiyama $Y$, et al. Survival significance of coexisting chronic obstructive pulmonary disease in patients with early lung cancer after curative surgery. Thoracic Cancer. 2018;9(1): 19-24.

17. Yasuura $\mathrm{Y}$, Maniwa T, Mori K, Miyata N, Mizuno K, Shimizu R, et al. Quantitative computed tomography for predicting cardiopulmonary complications after lobectomy for lung cancer in patients with chronic obstructive pulmonary disease. General Thoracic and Cardiovascular Surgery. 2019;67(8): 697-703.

18. Peer M, Stav D, Cyjon A, Sandbank J, Vasserman M, Haitov $Z$, et al. Morbidity and mortality after major pulmonary resections in patients with locally advanced stage IIIA non-small cell lung carcinoma who underwent induction therapy. Hear, Lung \& Circulation. 2015;24(1): 69-76.

19. Venuta F, Anile M, Diso D, Ibrahim M, De Giacomo T, Rolla M, et al. Operative complications and early mortality after induction therapy for lung cancer. European Journal of Cardio-Thoracic Surgery. 2007;31(4): 714-717.

20. Stamatis G, Eberhard W, Pöttgen C. Surgery after multimodality treatment for non-small-cell lung cancer. Lung Cancer. 2004;45: S107-S112.

21. Refai M, Brunelli A, Rocco G, Ferguson MK, Fortiparri SN, Salati $M$, et al. Does induction treatment increase the risk of morbidity and mortality after pneumonectomy? A multicentre case-matched analysis. European Journal of Cardio-Thoracic Surgery. 2010;37(3): 535-539.

22. Satoh Y. Management of chest drainage tubes after lung surgery. General Thoracic and Cardiovascular Surgery. 2016;64(6): 305-308.

23. Coughlin S, Emmerton-Coughlin H, Malthaner R. Management of chest tubes after pulmonary resection: A systematic review and meta-analysis. Canadian Journal of Surgery. 2012;55(4): 264-270.

24. Rizzardi G, Bortolotti L. Risk factors and 90-day mortality after video-assisted thoracoscopic lobectomy for lung cancer: The discussion is still open. Video-Assisted Thoracoscopic Surgery. 2018;3: 2.

25. Brunelli A, Dinesh P, Woodcock-Shaw J, Littlechild D, Pompili C. Ninety-day mortality after video-assisted thoracoscopic lobectomy: Incidence and risk factors. The Annals of Thoracic Surgery. 2017;104(3): 1020-1026.

26. D'Amico TA. Defining and improving postoperative care. The Journal of Thoracic and Cardiovascular Surgery. 2014;148(5): 1792-1793. 